\title{
Pengaruh Inklusi Perbankan Syariah terhadap Pembiayaan UMKM Halal di Indonesia Periode 2017-2020
}

\author{
Ahmad Afandi \\ Pascasarjana Ekonomi Syariah, Fakultas Ekonomi dan Bisnis Islam, UIN Sunan Kalijaga, \\ Yogyakarta \\ Jl. Laksda Adisucipto, Papringan, Caturtunggal, Kec. Depok, Kabupaten Sleman, \\ Daerah Istimewa Yogyakarta, 55281 \\ E-mail: ahmadafandi0311@gmail.com
}

\begin{abstract}
ABSTRAK
Penelitian ini bertujuan menganalisis dimensi inklusi keuangan perbankan dengan jumlah kantor perbankan syariah yaitu Bank Umum Syariah dan Unit Usaha Syariah terhadap pembiayaan UMKM halal di Indonesia periode 2017-2020. Jenis penelitian ini kuantitatif dan menggunakan metode VAR (Vector Autoregression) untuk menganalisis pengaruh dimensis inklusi keuangan terhadap pembiyaan UMKM halal di perbankan syariah. Peneliti melakukan analisis kausalitas granger untuk menginterpretasikan hasil estimasi VAR. Hasilnya jumlah Bank Umum Syariah dan Unit Usaha Syariah tidak sepenuhnya mempengaruhi pembiayaan UMKM halal di perbankan syariah. Hasil dari penelitian ini juga memberikan kontribusi literasi dibidang keuangan terkait akses pembiayaan UMKM berbasis halal pada perbankan syariah di Indonesia.
\end{abstract}

Kata kunci: Inklusi Keuangan, Pembiayaan UMKM, Perbankan Syariah.

\begin{abstract}
This study aims to analyze the dimensions of banking financial inclusion with the number of Islamic banking offices, namely Islamic Commercial Banks and Sharia Business Units on halal MSME financing in Indonesia for the 2017-2020 period. This type of research is quantitative and uses the VAR (Vector Autoregression) method to analyze the influence of the dimensions of financial inclusion on the financing of halal MSMEs in Islamic banking. Researchers conducted a Granger causality analysis to interpret the VAR estimation results. As a result, the number of Islamic Commercial Banks and Sharia Business Units does not fully affect the financing of halal MSMEs in Islamic banking. The results of this study also contribute to financial literacy related to access to halal-based MSME financing in Islamic banking in Indonesia.
\end{abstract}

Keyword: Financial Inclusion, MSMEs Financing, Islamic Banking.

\section{PENDAHULUAN}

Perbankan syariah tidak dapat dipisahkan dari kerangka keuangan Indonesia secara keseluruhan. Setelah dikeluarkannya UU No. 21 tahun 2008, Bank syariah mendapatkan premis hukum yang khusus dan kuat serta lebih tegas (Sjahdeini, 2014). Undang-undang No. 21 tahun 2008 menjadi aturan dasar yang memuat struktur dan kewajiban keuangan Islam secara keseluruhan, menyimpulkan bahwa aturan keuangan Islam dan konvensional dikendalikan dalam undang-undang yang terpisah (Mujib, 2015). 
Perbankan syariah saat ini menghadapi kemajuan yang sangat cepat. Informasi dari Komite Nasional Keuangan Syariah (KNKS) menyatakan bahwa Global Islamic Finance Market sebesar US\$2,438 triliun dari tahun 2017 diperkirakan akan terus berkembang menjadi US\$ 3,809 triliun (naik 56\%) pada tahun 2023 (KNKS, 2019) . Melihat potensi yang sangat besar ini, Negara-negara Muslim dan non-Muslim bersaing untuk menciptakan perusahaan berbasis syariah. Indonesia sebagai salah satu negara dengan populasi Muslim terbesar di dunia, merupakan negara yang dianggap memiliki pintu masuk terbaik dalam membuat industri halal dunia. Tidak ada bedanya mengembangkan keuangan islam dengan cepat di Indonesia, jelas ada beberapa hambatan yang signifikan terkait dengan itu. Seperti market share keuangan Islam masih rendah keuangan konvensional (Hidayat \& Trisanty, 2020).

Hasil dari beberapa penyelidikan mengungkap penyebab kecilnya market share dan kemajuan perbankan syariah di Indonesia. Rendahnya kemampuan literasi perbankan syariah menjadi salah satu alasan mengapa individu masih kurang tertarik menggunakan produk dan layanan keuangan syariah (Nasution \& Fatira AK, 2019). Meningkatkan sosialisasi perbankan syariah secara umum dapat meningkatkan kelangsungan pelaksanaan perbankan syariah. Dengan masyarakat yang sebelumnya memiliki informasi dan pemahaman yang baik tentang perbankan syariah dan perekonomian Indonesia, masyarakat secara keseluruhan saat ini tidak perlu lagi mencermati penyajian kinerja perbankan syariah (Rahman, 2016).

Tingkat pendidikan dan pekerjaan juga sangat mempengaruhi pilihan individu untuk menabung di bank syariah (Huda, 2017). Perlu ada strategi meningkatkan market share untuk membangun porsi industri secara keseluruhan dari komponen masyarakat yang dilakukan oleh perbankan syariah. Dengan demikian, market share bank syariah akan meningkat lebih jauh. Selain market share yang tergolong rendah, literasi keuangan juga saat ini masih rendah. Indeks literasi dan inklusi syariah hanya $8,93 \%$ - 9,1\%. Untuk sementara, tingkat literasi dan inklusi konvesional telah mencapai 38,03\% sampai 76,19\% (OJK, 2020). Inklusi keuangan merupakan upaya untuk mendorong kerangka keuangan agar terbuka untuk semua lapisan masyarakat, sehingga meningkatkan pembangunan keuangan yang berkualitas serta mengalahkan kemiskinan (Adriani \& Wiksuana, 2018).

Inklusi keuangan dalam perspektif syariah merupakan upaya membangun keterbukaan publik terhadap keuangan syariah, sehingga masyarakat dapat mengawasi dan menyampaikan keuangan sesuai standar syariah (Steelyana, 2013). Peningkatan jaringan kantor perbankan syariah juga dapat mempengaruhi inklusi keuangan syariah. Perbankan syariah dalam beberapa tahun terakhir tampaknya telah berkembang secara signifikan. Pada tahun 2020 
jumlah bank syariah telah mencapai 14 Bank Umum Syariah, 20 Unit Usaha Syariah, dan 163 Bank Pembiayaan Rakyat Syariah, dengan 3.062 jaringan kantor yang tersebar di seluruh Indonesia (OJK, 2020).

Melihat perkembangan perbankan syariah yang mulai berkembang pesat akhir-akhir ini, semakin banyak orang yang harus memanfaatkan produk dan administrasi keuangan syariah. Dengan asumsi perbankan syariah tidak melakukan inovasi terkait layanan dan jaringan, ada tanda-tanda bahwa nasabah akan beralih untuk menyimpan uang dengan akses yang lebih terjangkau. Penting bagi perusahaan untuk menarik nasabah dan menahan mereka agar perusahaan dapat bertahan dan maju (Mawarni et al., 2021). Selain nasabah yang menggunakan produk dan administrasi akan mengalami kerugian, nasabah pembiayaan juga akan berkurang. Dengan tujuan akan mempengaruhi peluang penyaluran pembiayaan dan peluang menciptakan keuntungan (Harmoko, 2018).

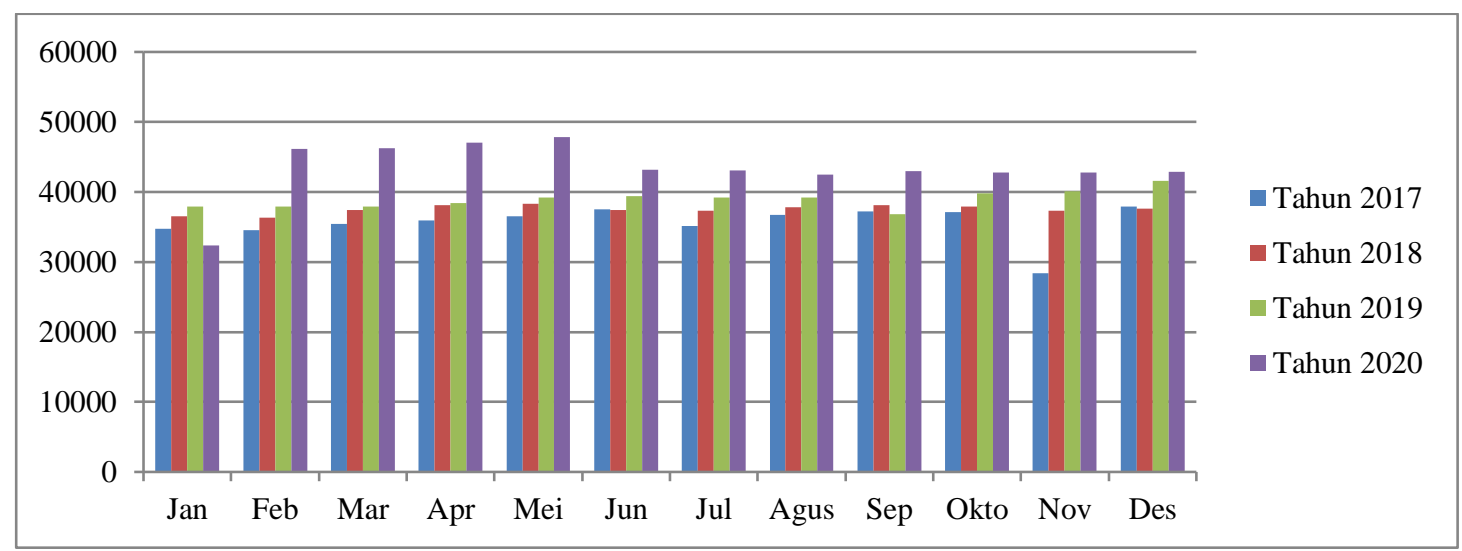

Gambar 1. Jumlah Pembiayaan Syariah Pada UMKM 2017-2020

Sumber: www.ojk.co.id

Gambar diatas menunjukan bahwa jumlah pembiayaan syariah pada UMKM tahun 2017-2020, mengalami kenaikan setiap tahunnya. Apabila jumlah kantor layanan perbankan syariah meningkat, maka pembiayaan akan meningkat (Mustofa, 2019). Begitupula dengan simpanan atau DPK, jaringan perusahaan yang luas diperlukan untuk mempercepat peningkatan dalam meningkatkan penghimpunan dana (Abdullah, 2013). UMKM (Usaha Mikro Kecil dan Menengah) merupakan salah satu andalan perekonomian di Indonesia, hal ini dikarenakan jumlah UMKM yang sangat banyak di Indonesia (Permana, 2017). Pelaku bisnis saat ini sangat mengutamakan tentang pentingnya faktor halal dalam barang-barang yang mereka tawarkan kepada masyarakat.

Jadi prosedur mendasar melalui UMKM halal untuk menghadapi persaingan di seluruh dunia adalah dengan memperluas sertifikat UMKM halal, memperluas kemampuan sumber daya manusia UMKM halal, menggunakan kemajuan saat ini dan tepat untuk memenuhi 
aturan item halal UMKM, memperkuat keterkaitan dengan industri (hilirisasi), meningkatkan item UMKM, membangun upaya bersama dengan asosiasi terkait untuk kemajuan halal barang dagangan UMKM, memperluas cap produk UMKM halal melalui pengembangan dan media informasi, dan memperkuat bacaan fikih untuk penyampaian produk UMKM halal (Pujiono et al., 2018).

UMKM memainkan peran dominan dibandingkan dengan usaha lainnya, serta memiliki pilihan untuk mengasimilasi pekerja UMKM hanya sebagai penanda perkembangan pertumbuhan ekonomi Indonesia. Sebagian besar berpendapat bahwa masalah utama dalam UMKM adalah permodalan dan pembiayaan, sehingga pekerjaan lembaga keuangan, khususnya bidang perbankan menjadi perhatian utama(Hadiwidjaja \& Hartati, 2013). Semakin mudah UMKM halal untuk mendapatkan pembiayaan syariah, UMKM mungkin bisa membangun omzet usaha (Muhadjirin, 2017). Melihat informasi dan paparan tersebut, maka peneliti perlu mengkaji pengaruh inklusi keuangan syariah terhadap pembiayaan UMKM halal di perbankan syariah di Indonesia dari tahun 2017 hingga 2020.

Berbeda dengan penelitian yang dilakukan oleh beberapa peneliti lainnya yang masih berfokus pada penghimpunan dana pihak ketiga, seperti tabungan dan produk deposito syariah juga peran pengembangan UMKM (Hidayanti, 2016; Kamarni \& Handra, 2019; Muheramtohadi, 2017). Penelitian sejalan terkait perbankan syariah juga dapat membangun akses pembiayaan syariah bagi pelaku UMKM (Ahyar, 2019; Isrowiyah, 2019). Berdasarkan keterangan di atas, selanjutnya memunculkan hipotesis penelitian antara lain:

$\mathrm{H}_{1}$ : Pembiayaan UMKM halal menyebabkan kausalitas granger terhadap jumlah BUS dan UUS

$\mathrm{H}_{2}$ : Jumlah BUS dan UUS menyebabkan kausalitas granger terhadap pembiayaan UMKM halal.

\section{METODE PENELITIAN}

Pada penelitian ini, pendekatan yang digunakan dalam pengujian ini adalah pendekatan kuantitatif. Kuantitatif digunakan karena penelitian yang akan diselesaikan akan menggunakan alat ukur statistik, alat tersebut akan menguji hipotesis dan kemudian merangkumnya sebagai informasi (Ahmad et al., 2019). Data yang digunakan yaitu data sekunder yang merupakan data time series dari satu bulan ke bulan atau dari Januari 2017 hingga Desember 2020. Data sekunder yang digunakan meliputi jumlah Bank Umum Syariah (BUS), dan Unit Usaha Syariah (UUS), dengan pembiayaan UMKM halal di perbankan syariah. Penelitian ini membahas tentang pengaruh inklusi keuangan syariah terhadap 
pembiayaan UMKM halal di Indonesia. Seluruh data tersebut diperoleh melalui Statistik Perbankan Syariah yang disesuaikan oleh Otoritas Jasa Keuangan (OJK) secara konsisten dan dipublish melalui situs OJK (www.ojk.go.id)

Adapun variabel penelitian ini adalah jumlah BUS dan UUS kemudian pembiayaan UMKM yang terdapat di bank syariah. Kantor bank syariah merupakan tempat bank syariah dalam melayani nasabah untuk menawarkan jenis bantuan untuk berbagai jenis produk dan administrasi bank syariah, seperti produk dana investasi, pembiayaan, gadai, dan lain sebagainya. Kantor bank syariah terdiri dari pertama kantor pusat, kedua kantor cabang, ketiga kantor cabang pembantu dan kantor bank syariah yang terakhir yaitu kantor kas. Semua informasi terkait variabel ini diperoleh melalui Statistik Perbankan Syariah yang dapat diunduh melalui situs Otoritas Jasa Keuangan (OJK).

Dalam teknik penelitian ini, alat analisis yang digunakan adalah aplikasi E-Views 9. Penelitian ini berpusat pada faktor inklusi keuangan pada pembiayaan UMKM halal di bank syariah. Peneliti menggunanakan strategi atau teknik VAR (Vector Autoregression) untuk menganalisis dampak dari dimensi inklusi keuangan pada pembiayaan UMKM halal di perbankan syariah.Sebelum menyelesaikan prosedur penggunaan strategi VAR, peneliti mengarahkan beberapa uji investigasi data yang akan digunakan, misalnya uji stasioneritas data (uji root test), uji kointegrasi, uji lag length, model Regresi Vector Autoregression, dan uji VAR. Kemudian peneliti menggunakan analisis variance decomposition dan uji kausalitas Granger (granger causality test) untuk interprestasi akhir dari penelitian.

\section{HASIL DAN PEMBAHASAN}

\section{Uji Stationeritas Data (Root Test)}

Uji stationeritas data digunakan untuk menunjukkan stabilitias (normalitas) contoh dari setiap faktor atau variabel, sehingga regresi yang terjadi tidak palsu sehingga tidak memberikan pemahaman yang salah. Untuk hasil uji stasioneritas pada tabel 1 dan 2:

Tabel 1. Hasil Uji Stationeritas Jumlah BUS \& UUS

\begin{tabular}{lrcc}
\hline & \multicolumn{1}{c}{ t-Statistic } & Prob.* \\
\hline \multicolumn{2}{l}{ Augmented Dickey-Fuller test statistic } & -16.96817 & 0.0000 \\
\hline Test critical values: & $1 \%$ level & -3.584743 & \\
& $5 \%$ level & -2.928142 & \\
& $10 \%$ level & -2.602225 & \\
\hline
\end{tabular}

Sumber: data diolah 2021

Diketahui bahwa nilai probabilitas adalah 0,0000 lebih kecil dari 0,05 $(0,0000<0,05)$, maka variabel stasioner dan dapat dilakukan pengujian selanjutnya. 
Tabel 2. Hasil Uji Stasioneritas Pembiayaan UMKM Halal

\begin{tabular}{lrrr}
\hline & & \multicolumn{1}{c}{ t-Statistic } & \multicolumn{1}{c}{ Prob.* } \\
\hline Augmented Dickey-Fuller test statistic & -11.48664 & 0.0000 \\
Test critical values: & 1\% level & -3.581152 & \\
& 5\% level & -2.926622 & \\
\hline $10 \%$ level & -2.601424 & \\
\hline
\end{tabular}

Sumber: data diolah 2021

Diketahui bahwa nilai probabilitas adalah 0,0000 lebih kecil dari 0,05 $(0,0000<0,05)$, maka variabel stasioner dan dapat dilakukan pengujian selanjutnya.

\section{Uji Kointegrasi}

Uji kointegrasi pada hakikatnya adalah untuk menentukan peluang atau kemungkinan terjadinya hubungan harmonis yang berlarut-larut pada variabel yang hendak dilakukan observasi. Hasil uji kointegrasi dilihat pada tabel 3:

Tabel 3. Hasil Uji Kointegrasi

\begin{tabular}{ccccc}
\hline $\begin{array}{c}\text { Hypothesized } \\
\text { No. of CE(s) }\end{array}$ & Eigenvalue & $\begin{array}{c}\text { Trace } \\
\text { Statistic }\end{array}$ & $\begin{array}{c}\mathbf{0 . 0 5} \\
\text { Critical Value }\end{array}$ & Prob.** \\
\hline None $*$ & 0.240277 & 17.46597 & 15.49471 & 0.0249 \\
At most $1 *$ & 0.099580 & 4.825127 & 3.841466 & 0.0280 \\
\hline
\end{tabular}

Sumber: data diolah 2021

Diketahui bahwa nilai trace statistic lebih besar daripada critical value. Dapat disimpulkan hal ini bahwa trace statistic cenderung menunjukan lebih besar daripada critical value, yaitu 4,825127 > 3,841466, yang berarti ada hubungan kointegrasi.

\section{Uji Lag Length}

Hasil uji lag length berarti menunjukkan lag length yang digunakan memadai. Pengujian lag length dilihat pada tabel 4:

Tabel 4. Hasil Uji Lag Length

\begin{tabular}{crccccc}
\hline Lag & LogL & LR & FPE & AIC & SC & HQ \\
\hline 0 & -659.0963 & NA & $3.85 \mathrm{e}+10$ & 30.04983 & 30.13093 & 30.07991 \\
1 & -584.8487 & $138.3706^{*}$ & $1.58 \mathrm{e}+09^{*}$ & $26.85676^{*}$ & $27.10006^{*}$ & $26.94698^{*}$ \\
2 & -584.1304 & 1.273193 & $1.84 \mathrm{e}+09$ & 27.00593 & 27.41143 & 27.15631 \\
3 & -580.9961 & 5.271347 & $1.92 \mathrm{e}+09$ & 27.04528 & 27.61298 & 27.25581 \\
4 & -580.5387 & 0.727778 & $2.27 \mathrm{e}+09$ & 27.20630 & 27.93620 & 27.47698 \\
\hline
\end{tabular}

Sumber: data diolah 2021

Diketahui bahwa tanda (*) paling banyak ditemukan pada lag 1 . Hal ini menunjukkan atau menggambarkan bahwa lag ideal yang disarankan pada lag 1. Penentuan lag adalah untuk menghindari masalah heteroskedastisitas dan autokorelasi.

\section{Uji Vector Autoregression (VAR)}

Model VAR dapat dimanfaatkan untuk melihat hubungan pada periode yang akan dimanfaatkan atau digunakan. Hasil model VAR dapat dilihat tabel 5: 
Tabel 5. Hasil Uji Vector Autoregression (VAR)

\begin{tabular}{lcc}
\hline & X_BUS_UUS & Y_Pembiayaan_UMKM \\
\hline X_BUS_UUS(-1) & 0.979916 & 21.46582 \\
& $(0.06871)$ & $(12.8028)$ \\
X_BUS_UUS(-2) & {$[14.2625]$} & {$[1.67665]$} \\
& 0.090029 & 7.836273 \\
& $(0.05881)$ & $(10.9580)$ \\
Y_P_UMKM (-1) & {$[1.53097]$} & {$[0.71512]$} \\
& 0.000201 & 0.130396 \\
Y_P_UMKM (-2) & $(0.00084)$ & $(0.15745)$ \\
& {$[0.23776]$} & {$[0.82816]$} \\
C & -0.000257 & 0.127577 \\
& $(0.00085)$ & $(0.15791)$ \\
& {$[-0.30375]$} & {$[0.80791]$} \\
& -148.7677 & -36594.08 \\
& $(91.9430)$ & $(17132.9)$ \\
\hline
\end{tabular}

Sumber: data diolah 2021

Secara umum akan terlihat bahwa nilai t-test yang melebihi 2 (dua) menunjukkan bahwa variabel tersebut memiliki pengaruh yang besar. Pada tabel di atas, terlihat bahwa BUS dan UUS bertanda (-1) tidak berpengaruh terhadap pembiayaan UMKM halal mengingat nilai uji-t $(1,67665)$ pada faktor ini lebih kecil dari dua. Kemudian, pada saat itu, pembiayaan UMKM bertanda (-1) tidak berdampak pada BUS dan UUS, karena nilai uji-t $(0,23776)$ yang diperoleh juga lebih rendah dari dua.

\section{Uji Stabilitas VAR}

Uji stabilitas VAR direncanakan untuk mengetahui apakah kerangka itu stasioner atau tidak. Uji stabilitas VAR dilihat pada tabel 6:

Tabel 6. Hasil Uji Stabilitas VAR

\begin{tabular}{ll}
\hline Root & Modulus \\
\hline $0.124350-0.776867 \mathrm{i}$ & 0.786756 \\
$0.124350+0.776867 \mathrm{i}$ & 0.786756 \\
$-0.552697-0.454924 \mathrm{i}$ & 0.715842 \\
$-0.552697+0.454924 \mathrm{i}$ & 0.715842 \\
-0.613367 & 0.613367 \\
$0.541616-0.271249 \mathrm{i}$ & 0.605743 \\
$0.541616+0.271249 \mathrm{i}$ & 0.605743 \\
-0.073994 & 0.073994 \\
\hline
\end{tabular}

Sumber: data diolah 2021

Dapat terlihat bahwa modulus, yang merupakan nilai langsung dari akar atau root, kurang dari yang satu. Selanjutnya, cenderung diuraikan bahwa stasioner itu tetap.

\section{Uji Analisis Model Variance Decomposition}

Model Variance Decomposition (VDC) meneruskan data sebagai tingkat perkembangan secara berurutan karena kejutan aktual dari berbagai variabel. Analisis Variance 
Decomposition (VDC) digunakan untuk mengukur komitmen atau penciptaan dampak setiap variabel bebas terhadap variabel terikat. Model Analisis Variance Decomposition (VDC) dapat dilihat pada tabel 7 dan 8 :

Tabel 7. Hasil Model Variance Decomposition

\begin{tabular}{cccc}
\hline \multicolumn{4}{c}{ Jumlah Jaringan BUS \& UUS } \\
\hline Period & S.E. & BUS \&UUS & P. UMKM \\
\hline 1 & 2908.440 & 100.0000 & 0.000000 \\
2 & 3352.904 & 98.47194 & 1.528061 \\
3 & 4351.010 & 58.48628 & 41.51372 \\
4 & 5317.080 & 39.34401 & 60.65599 \\
5 & 5442.626 & 37.70484 & 62.29516 \\
6 & 5456.269 & 37.59457 & 62.40543 \\
7 & 5459.298 & 37.65350 & 62.34650 \\
8 & 5468.028 & 37.53337 & 62.46663 \\
9 & 5507.994 & 37.90339 & 62.09661 \\
10 & 5560.959 & 39.01872 & 60.98128 \\
\hline
\end{tabular}

Sumber: data diolah 2021

Melihat Variance Decomposition pada variabel BUS dan UUS dalam kerangka waktu pertama menunjukkan bahwa tidak ada penting bagi variabel yang dapat mempengaruhi perubahan besaran atau fluktuasi variabel BUS dan UUS, karena angka tersebut menunjukkan 100\%. Namun demikian, dalam kurun waktu berikutnya, hingga jangka waktu kesepuluh, ada bagian variabel pembiayaan UMKM yang juga mempengaruhi variabel BUS dan UUS.

Tabel 8. Hasil Model Variance Decomposition

\begin{tabular}{cccc}
\hline \multicolumn{3}{c}{ Pembiayaan UMKM Halal } \\
\hline Period & S.E. & BUS \&UUS & P. UMKM \\
\hline 1 & 15.23275 & 0.047756 & 99.95224 \\
2 & 15.31728 & 0.094536 & 99.90546 \\
3 & 15.47070 & 1.020070 & 98.97993 \\
4 & 17.42668 & 10.54444 & 89.45556 \\
5 & 18.93411 & 13.12575 & 86.87425 \\
6 & 20.16427 & 14.17725 & 85.82275 \\
7 & 20.50451 & 13.72007 & 86.27993 \\
8 & 21.64100 & 14.83327 & 85.16673 \\
9 & 22.08204 & 16.53751 & 83.46249 \\
10 & 23.39286 & 16.16340 & 83.83660
\end{tabular}

Pada Variance Decomposition variabel pembiayaan UMKM halal untuk jangka waktu pertama, variabel BUS dan UUS menunjukkan angka 0,047756 dan variabel pembiayaan UMKM adalah 99.95224. Hal ini menunjukkan bahwa variabel jumlah BUS dan UUS hanya mempengaruhi sekitar $\pm 1 \%$ pembiayaan UMKM, yang berarti besarnya BUS dan UUS tidak sepenuhnya mempengaruhi pembiayaan UMKM yang disalurkan. Pada periode kedua dan seterusnya juga menunjukkan hal yang sama, bahwa besarnya BUS dan UUS tidak mempengaruhi penyaluran pembiayaan kepada UMKM halal. 


\section{Uji Analisis Granger Causality}

Analisis Granger Causality digunakan untuk melihat apakah variabel terdapat hubungan dua atau satu arah. Model granger causality dilihat pada tabel 9:

Tabel 9. Hasil Uji Analisis Granger Causality

\begin{tabular}{lccc}
\hline Null Hypothesis: & Obs & F-Statistic & Prob. \\
\hline Y_P_UMKM does not Granger Cause & & & \\
X_BUS_UUS & 46 & 0.06648 & 0.9358 \\
X_BUS_UUS does not Granger Cause & & & \\
Y_P_UMKM & & 4.02104 & 0.0254 \\
\hline
\end{tabular}

Sumber: data diolah 2021

Dilihat pada null hypothesis dapat dikatakan menolak H1, dengan alasan bahwa nilai probabilitas sebesar 0,9358 lebih besar daripada alpha $(\alpha) 5 \%(0,05)$. Dengan demikian, Pembiayaan UMKM halal di perbankan syariah tidak memiliki hubungan sebab akibat dengan variabel BUS dan UUS. Kemudian pada null hypothesis kedua, probabilitas sebesar 0,0254 yang lebih kecil dari alpha $(\alpha) 5 \%(0,05)$. Variabel BUS dan UUS dapat dikatakan memiliki hubungan sebab akibat terhadap pembiayaan UMKM di perbankan syariah.

Teknik kausalitas Granger yang digunakan penting untuk metodologi penguraian hasil penilaian VAR. Dengan menggunakan strategi atau prosedur ini, peneliti dapat melihat pengaruh antara variabel yang digunakan dalam penelitian ini. Peneliti dapat menarik kesimpulan pembiayaan UMKM halal di perbankan syariah tidak memiliki hubungan sebab akibat dengan variabel BUS dan UUS. Penelitian ini tidak sesuai dengan penelitian Novatul Isrowiyah (2019) dimana pembiayaan syariah pada sektor UMKM dipengaruhi inklusi syariah di Indonesia.

Kemudian, null hypothesis kedua memiliki probabilitas 0,0254 yang lebih kecil daripada alpha $(\alpha) 5 \%(0,05)$. Oleh karena itu, dapat diduga bahwa variabel BUS dan UUS memiliki hubungan sebab akibat terhadap pembiayaan UMKM halal di perbankan syariah. Sesuai penelitian Muhammad Ahyar (2019) bahwa banyaknya jumlah BUS dan UUS memiliki hubungan sebab akibat dengan pembiayaan UMKM halal pada perbankan syariah.

Melihat perkembangan perbankan syariah yang mulai berkembang pesat akhir-akhir ini, seharusnya semakin banyak orang yang harus memanfaatkan produk dan layanan keuangan syariah. Semua hal dipertimbangkan, karena peningkatan jumlah kantor dalam jangka waktu singkat tidak dapat ditanggapi dengan segera, tetapi perlu waktu, sehingga dampaknya akan lebih nyata dalam tahun-tahun berikutnya (Nofinawati, 2016). Kemungkinan informasi jumlah kantor bank syariah di tahun-tahun mendatang diproyeksikan akan terus berkembang sesuai dengan perkembangan keuangan Indonesia yang secara umum akan terus membaik (Mustofa, 2019). 
Fasilitas jaringan kantor juga berpengaruh terhadap akses pembiayaan UMKM perbankan syariah. Jaringan kantor yang baik akan menarik nasabah, karena lebih mudah mendapatkan informasi terkait pembiayaan (Putri \& Probosiwi, 2018). Selain itu masih minimnya pengetahuan dan pemahaman para penggiat UMKM terkait pembiayaan bank syariah masih menjadi penyebab utama (Arianto, 2020).

Industri keuangan syariah dapat melakukan berbagai inovasi untuk menumbuhkan masuknya pembiayaan bagi pelaku UMKM, khususnya bagi pelaku UMKM yang memasuki bisnis halal. Misalnya dengan menumbuhkan ide inovasi keuangan, seperti penyaluran pinjaman, teknologi digital berbasis keuangan dan lain-lain. Hal ini akan memudahkan sebagian pelaku UMKM untuk mendapatkan pembiayaan syariah.

\section{KESIMPULAN DAN SARAN}

Berdasarkan hasil penelitian terkait pengaruh inklusi keuangan terhadap pembiayaan UMKM halal di Indonesia periode 2017-2020, dapat disimpulkan bahwa cenderung diasumsikan bahwa BUS dan UUS tidak sepenuhnya mempengaruhi pembiayaan UMKM. halal di Indonesia. Hasil pengujian kausalitas Granger menunjukkan bahwa pembiayaan UMKM halal di perbankan syariah tidak memiliki hubungan sebab akibat dengan variabel BUS dan UUS di Indonesia. Sedangkan banyaknya jumlah BUS dan UUS memiliki sebab akibat terhadap pembiayaan UMKM halal.

Peneliti merekomendasikan kepada peneliti selanjutnya perlu mengembangkan topik ini dengan menambahkan berbagai variabel yang terkait dengan variabel inklusi keuangan. Jumlah kantor bank syariah hanyalah salah satu faktor yang menjunjung tinggi pertimbangan keuangan, karena kantor atau administrasi yang berada di dekat daerah akan memudahkan untuk mendapatkan berbagai produk dan administrasi perbankan syariah. Mungkin peneliti berikutnya bisa menambahkan variabel Bank Pembiayaan Rakyat Syariah selain Bank Umum Syariah dan Unit Usaha Syariah untuk melihat keadaan dan hasil akhir pembiayaan UMKM.

Informasi atau data penelitian adalah time series dari bulan ke bulan mulai dari Januari 2017 hingga Desember 2020, semuanya dalam 4 tahun terakhir. Peneliti selanjutnya dapat memeriksa 5 hingga 10 tahun terakhir atau menambahkan faktor moderasi dan variabel kontrol dalam penelitian. Dengan tujuan agar dampak inklusi perbankan terhadap pembiayaan UMKM halal dapat terlihat dengan jelas. Hasil dari penelitian ini diharapkan dapat bermanfaat bagi lembaga keuangan, khususnya bank syariah sebagai sumber referensi dan informasi tentang cara membuat strategi promosi yang baik di kemudian hari. Efek lanjutan 
dari penelitian ini menyimpulkan bahwa lembaga keuangan dan pemerintah perlu lebih mengembangkan pendidikan informasi atau edukasi keuangan dikalangan masyarakat.

\section{REFERENSI}

Abdullah. (2013). Analisis Faktor-faktor yang Mempengaruhi Penghimpunan Deposito Mudharabah Perbankan Syariah di Indonesia. Jurnal Akuntansi, 11(4), 595-604.

Adriani, D., \& Wiksuana, I. G. (2018). Inklusi Keuangan dalam Hubungannya dengan Pertumbuhan Umkm Dan Tingkat Kesejahteraan Masyarakat Di Provinsi Bali. E-Jurnal $\begin{array}{llll}\text { Manajemen Universitas } & \text { Udayana, } & 7(12), & \end{array}$ https://doi.org/10.24843/ejmunud.2018.v07.i12.p02

Ahmad, S., Wasim, S., Irfan, S., Gogoi, S., Srivastava, A., \& Farheen, Z. (2019). Qualitative v/s. Quantitative Research- A Summarized Review. Journal of Evidence Based Medicine and Healthcare, 6(43), 2828-2832. https://doi.org/10.18410/jebmh/2019/587

Ahyar, M. K. (2019). Analisis Pengaruh Inklusi Perbankan Syariah terhadap Pembiayaan UMKM Sektor Halal di Indonesia. Al-Tijary, 5(1), 19-36. https://doi.org/10.21093/at.v5i1.1716

Arianto, B. (2020). Pengembangan UMKM Digital di Masa Pandemi Covid-19. ATRABIS: Jurnal Administrasi Bisnis (e-Journal), 6(2), 233-247. https://www.jurnal.plb.ac.id/index.php/atrabis/article/view/512

Hadiwidjaja, R. D., \& Hartati, N. (2013). Tinjauan Umum Usaha Mikro Kecil dan Menengah di Indonesia : Permasalahan dan Strategi. Kewirausahaan Dalam Multi Perspektif, 137151. www.depkop.go.id

Harmoko, I. (2018). Mekanisme Restrukturisasi Pembiayaan pada Akad Pembiayaan Murabahah dalam Upaya Penyelesaian Pembiayaan Bermasalah. Jurnal Qawanin, 02, 61-80.

Hidayanti, R. (2016). Pengaruh BI Rate, Inflasi dan Jumlah Kantor Cabang terhadap Simpanan Mudharabah pada Bank Umum Syariah Tahun 2011-2014. Jurnal Akuntansi Unesa, 4(3).

Hidayat, A. R., \& Trisanty, A. (2020). Analisis Market Share Perbankan Syariah di Indonesia. At-Taqaddum, 12(2), 183-200. https://doi.org/10.21580/at.v12i2.6449

Huda, M. M. (2017). Pengaruh Pendidikan, Pekerjaan dan Pendapatan terhadap Minat Menabung di Bank SYariah (Studi Kasus Masyarakat Desa Kupen). IAIN Salatiga.

Isrowiyah, N. (2019). Indeks Inklusi Keuangan Syariah serta Pengaruhnya terhadap Pembiayaan Syariah pada Usaha Mikro, Kecil dan Menengah di Indonesia. UIN Walisongo Semarang.

Kamarni, N., \& Handra, H. (2019). Permintaan Pembiayaan Umkm ke Perbankan Syariah di Sumatera Barat. Maqdis: Jurnal Kajian Ekonomi Islam, 4(2), 151. https://doi.org/10.15548/maqdis.v4i2.254

KNKS. (2019). Komite Nasional Ekonomi dan Keuangan Syariah. Https://Www.PikiranRakyat.Com. https://knks.go.id/berita/14/ini-dia-yang-mendorong-tumbuhnya-trenindustri-halal-di-dunia?category $=2$

Mawarni, R., Fasa, M. I., \& Suharto. (2021). Penerapan Digital Banking Bank Syariah sebagai Upaya Customer Retantion pada Masa Covid-19. Jurnal Pemikiran dan Penelitian Ekonomi Islam, 9(2), 39-54. http://jurnal.staialazharmenganti.ac.id/index.php/AlIqtishod/article/view/233

Muhadjirin. (2017). Peranan Bank Syariah dalam Mengembangkan Usaha Mikro Kecil dan Menengah. Al-Ittihad Jurnal Pemikiran Dan Hukum Islam, 3(1), 71-84.

Muheramtohadi, S. (2017). Peran Lembaga Keuangan Syariah dalam Pemberdayaan UMKM 
di Indonesia. MUQTASID Jurnal Ekonomi dan Perbankan Syariah, 8(1), 95. https://doi.org/10.18326/muqtasid.v8i1.95-113

Mujib, A. (2015). Pendekatan Tafsir Produk Perbankan Syariah. Muqtasid: Jurnal Ekonomi Dan Perbankan Syariah, 6(1), 41. https://doi.org/10.18326/muqtasid.v6i1.41-57

Mustofa, A. (iain ponorogo. (2019). Analisis Pengaruh Jumlah Kantor Bank Umum Syariah (JKBUS), Sertifikat Bank Indonesia Syariah (SBIS), dan Dana Pihak Ketiga (DPK) terhadap Pembiayaan Bagi Hasil pada Bank Umum Syariah di Indonesia Periode 2015 2018. IAIN Ponorogo.

Nasution, A. W., \& Fatira AK, M. (2019). Analisis Faktor Kesadaran Literasi Keuangan. EQUILIBRIUM: Jurnal Ekonomi Syariah, 7(1), 40-63.

Nofinawati. (2016). Perkembangan Perbankan Syariah di Indonesia. JURIS (Jurnal Ilmiah Syariah), 14(2), 168. https://doi.org/10.31958/juris.v14i2.305

OJK. (2020). SPS Perbankan Syariah 2020. Ojk.

Permana, S. H. (2017). Strategi Peningkatan Usaha Mikro, Kecil, dan Menengah (UMKM) Di Indonesia. Aspirasi, 8(1), 93-103.

Pujiono, A., Setyawati, R., \& Idris, I. (2018). Strategi Pengembangan Umkm Halal di Jawa Tengah dalam Menghadapi Persaingan Global. Indonesia Journal of Halal, 1(1), 1. https://doi.org/10.14710/halal.v1i1.3109

Putri, P. I., \& Probosiwi, E. (2018). Akses Kredit Usaha Rakyat Umkm Anggota Klaster Olahan Pangan Kota Semarang. Jurnal REP (Riset Ekonomi Pembangunan), 3(1), 3947. https://doi.org/10.31002/rep.v3i1.791

Rahman, A. (2016). Analisis Faktor-faktor yang Mempengaruhi Market Share Bank Syariah. E-Journal UIN Sumatera Utara, 5(2), 24.

Sjahdeini, S. R. (2014). Perbankan Syariah Produk-Produk dan Aspek-Aspek Hukumnya. Kencana Prenadamedia Group.

Steelyana, E. (2013). Perempuan dan Perbankan: Sebuah Tinjauan Tentang Peran Inklusi Keuangan terhadap Pengusaha UMKM Perempuan di Indonesia. The Winners, 14(2), 95. https://doi.org/10.21512/tw.v14i2.649 